\title{
Soil enzymes and biological activity at different levels of organic matter stability
}

\author{
C. Merino ${ }^{1}$, R. Godoy ${ }^{2}$, F. Matus ${ }^{1,3.4^{*}}$

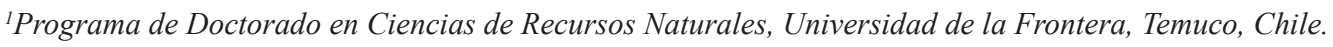 \\ ${ }^{2}$ Instituto de Ciencias Ambientales y Evolutivas, Universidad Austral de Chile. ${ }^{3}$ Departamento de Ciencias \\ Químicas y Recursos Naturales, Universidad de La Frontera, Temuco, Chile. ${ }^{4}$ Scientific and Technological \\ Bioresource Nucleus (BIOREN-UFRO),Universidad de La Frontera, Temuco, Chile. *Corresponding author: \\ francisco.matus@ufrontera.cl
}

\begin{abstract}
Soil biological activity has important implications for soil carbon (C) sequestration. However, very little is known about the environmental factors, particularly the effect of soil mineralogy on availability of $\mathrm{C}$ for soil microorganisms. In this study, we have investigated the influences of soil type (clay mineralogy) on C mineralization and its effects on biological activity at different levels of soil organic matter stability. Two soils an allophanic, derived from recent volcanic ash and a kaolinitic, resulting from metamorphic parent materials were physically fractioned in to light (LF, coarse sand 250-2000 $\mu \mathrm{m}$ ), intermediate (IF, fine sand53-250 $\mu \mathrm{m}$ ) and mineral (MF, silt and clay $<53 \mu \mathrm{m}$ ) fractions. Several biological and biochemical analyses at Ah horizons of mineral soil and physical fractions were conducted: soil respiration, enzymatic activities, carbohydrates and microbial biomass, amongst others soil variables. The results indicated that the bulk soil and physical fractions had a significant impact on cumulative $\mathrm{C}$ mineralized after 30 days of incubation and soil enzyme activities. More than $76 \%$ of total $\mathrm{C}-\mathrm{CO}_{2}$ variation was explained by stepwise multiple regression analysis including factors such as soil enzymes ( $\beta$-glucosidase, dehydrogenase and phosphatase) and inorganic P. Soil ATP extraction was a good indicator of microbial activity, because of a positive and significant correlation among ATP and i) $\mathrm{C}-\mathrm{CO}_{2}$ and ii) metabolic quotient (soil respiration rate divided by microbial biomass). We also found an inverse and significant relationship between $\mathrm{Al}$ pyrophosphate (Al bound to $\mathrm{SOM}$ ) and the $\mathrm{C}-\mathrm{CO}_{2}$ in volcanic soil, whereas the same correlation did not occur in kaolinitic soil. Our results confirmed a greater stabilization capacityof MF in allophanic than in kaolinitic soils due to the amorphous minerals clay materials.
\end{abstract}

Keywords: Soil physical fractionation, carbon mineralization, volcanic soils, mineral interaction 


\section{Introduction}

It is important to know how soil responds to environmental changes to predict the response of soil ecosystem to soil $\mathrm{C}$ sequestration under climatic change scenarios (Post et al., 2009; Nie et al., 2013; Zhao et al., 2014). For instance, the addition of fresh labile $C$ that generally induces an acceleration in the turnover of native soil organic matter (SOM), the priming effects, might causes an extra mineralization of $\mathrm{C}$, greater than fresh $\mathrm{C}$ incorporated into the soil.

From a physical point of view, the habitat for soil microorganisms is influenced not only bythe soil pore size distribution in the soil matrix, but also by the mineral composition and availability of C (Van Gestel et al., 1996; Barberán et al., 2014). It is well known that soil microbes are unable to assimilate solid SOM directly, but rather simple and dissolved compounds for their growth and development. Consequently, soil microbes produce extracellular enzymes to make readily usable dissolved compounds. For example, $\beta$-glucosidase, a hydrolytic enzyme that acts on $\beta-1,4$ linkage of oligomers, yield organic substances of low molecular weight and soluble compounds (Hammel, 1997). Another example, is shortage of the available nitrogen $(\mathrm{N})$ in soil limits the microbial activity, so soil microbes produce oxidative enzymes to degrade recalcitrant SOM and release the occluded N (Carreiro et al., 2000; Waldrop et al., 2004). Dornbush et al. (2007) found that the $\mathrm{N}$ content of grass litters had a positive correlation with the activity of $\beta$-glucosidase family enzymes. The release of microbial enzyme in response to the quantity andquality of SOM in different soil typeneeds to be better understood (Rasmussen et al., 2006; Kuzyakov, 2010). Soil physical fractionation and soil mineralogy might indicate different $\mathrm{C}$ stability and functionalities for microbial communities. Different methods of soil fractionation have been developed to study the mechanisms that control SOM stability and complexity. The most popular one, has been fractionation by using liquids with different densities for non-volcanic soils (Christensen 1992; Jastrow 1996; Six et al., 2002; Jolivet et al., 2003). In volcanic soils, the density fractionation has been scarcely reported (Panichini et al., 2012), due to intrinsic gel soil characteristics of the volcanic materials. However, the common method that is often applied in both soil types is the wet sieving (Kemper and Koch, 1966).

The present study was performed in the Andes and Coastal range old growth forest of Nothofagus spp. in southern Chile in allophanic soil derived from a volcanic ash and kaolinitic soil derived from metamorphic materials. These sites offer an ideal opportunity to investigate the influence of soil mineralogy on $\mathrm{C}$ stabilization in different physical fractions. The biological activity in response to soil mineral composition at different level of SOM stability can provide valuable information to study the nutrient conservation dynamics in pristine ecosystems respiration.

The aim of this study was to determine the biological activity in various physical fractions isolated from $\mathrm{Ah}$ mineral horizons from soils with contrasting mineralogy and stabilization capacity of SOM.

\section{Materials and Methods}

\subsection{Site characterization}

The present study was developed in volcanic soil derived from recent volcanic ash in the Andes range and in a kaolinitic soil in the Coastal range. Both sites belongs to temperate rain forest ecosystems in southern Chile. The volcanic soil is located in the Puyehue National Park (PNP) $\left(40^{\circ} 26^{\circ}-40^{\circ} 58^{\prime} \mathrm{S}\right.$ and $72^{\circ} 22^{\prime}-71^{\circ} 50$ ' $\left.\mathrm{W}\right)$ at 800 m.a.s.1. (Godoy et al., 2001; Oyarzún et al., 2004; Matus 
et al., 2006) in a virgin forest (Nothofagus betuloides (Mirb.) with a mean annual precipitation $>4,000 \mathrm{~mm}$ and mean annual temperature (MAT) $9.2{ }^{\circ} \mathrm{C}$ (Oyarzún et al., 2004). These soils display unique morphological, physical and chemical properties attributed to the composition of their mineral phase consisting of short range ordered (SRO) materials like allophane, imogolite, ferrihydrite and an important amount of Al- and Fe-SOM complexes (Matus et al., 2008). The second area of study is Alerce Costero National Park (PAC) $\left(40^{\circ} 12^{\prime} \mathrm{S}\right.$ and $73^{\circ} 26^{\prime} \mathrm{W}, 1000$ m.a.s.l.) in the summit of Cordillera de la Costa. The soil is developed from metamorphic-schist materials with dominant presence of kaolinite (Luzio et al., 2003). The PAC is an ancient forest (Fitzroya cupressoides (Mol.) Johnst., mixed with Weinmannia trichosperma Cav., and Notohofagus nitida (Phil). The sampling site was a huge area dominated by N. nitida, Saxegothaea conspicua (Lindl.) and Laureliopsis philippiana (Looser) Schodde (Monimiaceae). The mean annual precipitation is $>4.000$ $\mathrm{mm}$ and annual temperature fluctuates between 9.5 and $12.1^{\circ} \mathrm{C}$.

\subsection{Soil sampling}

Top Ah mineral horizon $(5-10 \mathrm{~cm})$ were sampled after organic litter horizon was removed.

The soils were transported immediately to the laboratory under cold conditions, homogenized, sieved to $<2$ $\mathrm{mm}$ and characterized by soil $\mathrm{pH}$ in water, soil organic $\mathrm{C}$ (SOC), total $\mathrm{N}$, inorganic $\mathrm{P}$ (Olsen) and other macronutrients (Table 1) (Matus et al., 2011; Garrido and Matus, 2012).
Table 1. Soil characteristics used in this study

\begin{tabular}{|c|c|c|}
\hline Analysis & PNP & PAC \\
\hline $\mathrm{SOC}^{1}(\%)$ & 11.0 & 9.9 \\
\hline $\mathrm{N}$ total $(\%)$ & 0.7 & 0.4 \\
\hline $\mathrm{C}$ to $\mathrm{N}$ & 16.3 & 23.6 \\
\hline $\mathrm{P}\left(\mathrm{mg} \mathrm{kg}^{-1}\right)$ Olsen & 9.0 & 4.0 \\
\hline $\mathrm{K}\left(\mathrm{mg} \mathrm{kg}^{-1}\right)$ & 207.0 & 86.0 \\
\hline $\mathrm{pH}_{\text {water }}$ & 5.7 & 4.5 \\
\hline Al pyrophosphate $\left(\mathrm{g} \mathrm{kg}^{-1}\right)$ & 11.0 & 5.7 \\
\hline \multicolumn{3}{|l|}{ Cations $\left(\operatorname{cmol}(+) \mathrm{kg}^{-1}\right.$ soil $)$} \\
\hline $\mathrm{K}$ & 0.5 & 0.2 \\
\hline $\mathrm{Na}$ & 0.1 & 0.1 \\
\hline $\mathrm{Ca}$ & 2.8 & 0.5 \\
\hline $\mathrm{Mg}$ & 0.7 & 0.6 \\
\hline $\mathrm{Al}$ (potasiumchloride) & 1.2 & 18.4 \\
\hline Saturation de $\mathrm{Al}(\%)$ & 22.4 & 93.5 \\
\hline $\mathrm{CEC}^{2}\left(\operatorname{cmol}(+) \mathrm{kg}^{-1}\right.$ soil $)$ & 5.3 & 19.7 \\
\hline Base sat. $\left(\mathrm{cmol}(+) \mathrm{kg}^{-1}\right.$ soil $)$ & 4.1 & 1.3 \\
\hline Clay type ${ }^{3}$ & allophane & kaolinit \\
\hline Texture $^{4}$ & SL & $\mathrm{CL}$ \\
\hline
\end{tabular}

${ }^{1}$ Soilorganiccarbon

${ }^{2}$ Cation exchange capacity

${ }^{3}$ Luzio et al. (2003); Neculman et al. (2014)

${ }^{4} \mathrm{SL}=$ silty loam and $\mathrm{CL}=$ clay loam

2.3.Physical fractionation of soil organic matter (SOM)

We used Balesdent et al. (1991) method for physical fractionation. From each soil, three physical fractions were obtained in triplicate after removing the floatable in water organic materials: Light fraction (LF, coarse sand $>250 \mu \mathrm{m}$ ), intermediate fraction (IF, fine sand 50$250)$ and mineral fraction (MF, silt and clay $<53 \mu \mathrm{m}$ ) Briefly, a portion of $50 \mathrm{~g}$ of moist soil sample was suspended in $180 \mathrm{~mL}$ of demineralized water in a $500 \mathrm{~mL}$ 
capped plastic bottle with flat bottom containing 10 glass beads ( $5 \mathrm{~mm}$ diameter). After $16 \mathrm{~h}$ shaking (40 cycles $\mathrm{min}^{-1}$ ) the soil suspension was poured into a $250 \mu \mathrm{m}$ sieve. Material remaining on the sieve consisted of large and small visible fragment sof plant and animal structures plus coarse sand size particles. The material retained by the sieve was placed in a glass beaker and washed several times with water. We collect any floating material. Soil material $<250$ $\mu \mathrm{m}$ consisted in fine sand particles and MF. The last fraction was separated using $53 \mu \mathrm{m}$ sieve. The MF is assumed to be micro-aggregates composed of silt and clay, whereas IF is assumed to be the fine sand size grain and LF is composed from coarse sand. All soil samples were oven dried at $35^{\circ} \mathrm{C}$.

\subsection{Incubation of bulk soils physical fractions}

About $10 \mathrm{~g}$ (dry weight basis) of bulk soil and physical fractions (previously inoculated) were placed in $250 \mathrm{ml}$ flask (Schott) with a tight rubber stopper and incubated at $60 \%$ of field capacity $(-33 \mathrm{kPa})$ for seven days at $26 \pm 2{ }^{\circ} \mathrm{C}$ in dark. We assume that this procedure allowed removing the particulate organic matter fraction. At the end of pre-incubation, cellulose substrates ( $1 \mathrm{mg} \mathrm{C} \mathrm{g}^{-1}$ soil) was added.

All soils were again incubated with three replicates with $10-\mathrm{ml}$ of $0.5 \mathrm{M} \mathrm{NaOH}$. At each sampling 1, 3, 7,15 and 30 days of incubation, the $\mathrm{NaOH}$ was potentiometrically titrated back with $0.5 \mathrm{M} \mathrm{HCl}$. The $\mathrm{C}$ mineralization rates $\left(\mathrm{d}^{-1}\right)$ were determined as:

$$
\mathrm{C}-\text { mineralization rate }=\frac{\operatorname{Ln}\left(\mathrm{Ct}_{2}\right)-\mathrm{Ln}\left(\mathrm{Ct}_{1}\right)}{\mathrm{t}_{2}-\mathrm{t}_{1}}
$$

where, $\mathrm{C}_{1}$ and $\mathrm{C}_{2}$ is the cumulative $\mathrm{C}$ mineralization $\left(\mathrm{mg} \mathrm{C}-\mathrm{CO}_{2}\right)$ at $\mathrm{t}_{1}$ and $\mathrm{t}_{2}$, respectively.

Mineral $\mathrm{N}$ (ammomium and nitrate) was extracted with $1 \mathrm{M} \mathrm{KCl}$ solution for $1 \mathrm{~h}$ at a soil-solution ratio of 1:10. Mineral $\mathrm{N}$ was measured by the Kjeldahl method with magnesium oxide ( $\mathrm{MgO})$ and Devarda's alloy. Inorganic phosphorus was determined by the method Olsen (Olsen et al., 1954). Olsen-P was measured by extracting with $0.5 \mathrm{M} \mathrm{NaHCO}_{3}$ adjusted to pH 8.5. (Matus et al.,2011; Garrido and Matus, 2012)

\subsection{Biological and biochemical analysis}

\subsubsection{Microbial biomass $\mathrm{C}$ quotient}

Microbial biomass C (MB-C) was determined by fumigation of the sample with ethanol-free $\mathrm{CHCl}_{3}$ and extraction with $0.5 \mathrm{M} \mathrm{K}_{2} \mathrm{SO}_{4}$, according to Vance et al. (1987). Soil metabolic quotient $\left(q \mathrm{CO}_{2}\right)$ was calculated as the soil respiration rate divided by microbial biomass C (Anderson and Domsch, 1990) and served as indicator of microbial metabolic $\mathrm{C}$ use efficiency present in the sample.

\subsubsection{Enzyme activity}

We determined the activity of four enzymes: $\beta$-glucosidase, dehydrogenase, urease and acid phosphatase. The reference method for the determination of these enzyme activities is described by Tabatabai (1982) and Eivazi and Tabatabai (1988). Dehydrogenase activity was determined by the reduction of 2-p-iodo-nitrophenyl-phenyltetrazolium chloride (INT) to iodo-nitrophenyl formazan (INTF). 
Dehydrogenase activity was measured in soil, following incubation in the dark with $0.2 \mathrm{ml}$ of $0.4 \%$ INT in distilled water for $20 \mathrm{~h}$ at $22{ }^{\circ} \mathrm{C}$. The INTF was extracted with $10 \mathrm{ml}$ of methanol by shaking vigorously for 1 min and filtering through a Whatman $\mathrm{N}^{\circ} 5$ filter paper. The INTF was measured spectrophotometrically at $490 \mathrm{~nm}$. Urease activities were determined in $0.1 \mathrm{M}$ phosphate buffer at $\mathrm{pH} 7 ; 1 \mathrm{M}$ urea. Two $\mathrm{ml}$ of buffer were added tothe soil sample (in triplicated), which was incubated at $37^{\circ} \mathrm{C}$ for $30 \mathrm{~min}$. Both activities were determined by the released $\mathrm{NH}_{4}$ (Nannipieri et al., 1980). Phosphatase and $\beta$-glucosidase activities were determinedusing $\mathrm{p}$-nitrophenyl phosphate disodium or p-nitrophenyl-b-d-glucopyranoside as substrates, respectively (Masciandaro et al.,1994). Two $\mathrm{ml}$ of $0.1 \mathrm{M}$ maleate buffer (pH 6.5 for both phosphatase and $\beta$-glucosidase activities) and $0.5 \mathrm{ml}$ substrate were added to $0.25 \mathrm{~g}$ of sample and incubated at 37 ${ }^{\circ} \mathrm{C}$ for $90 \mathrm{~min}$. The reaction was stopped by cooling down; $0.5 \mathrm{M} \mathrm{CaCl} 2$, then $2 \mathrm{ml}$ of $0.5 \mathrm{M} \mathrm{NaOH}$ were added and the mixture centrifuged at $2000 \mathrm{~g}$ for $5 \mathrm{~min}$. To stop the $\beta$-glucosidase assay, trishydroxymethylaminomethane wasused according to Tabatabai (1982). The amount of p-nitrophenol was determined using a spectrophotometer at $398 \mathrm{~nm}$ (Tabatabai and Bremner,1969).

\subsubsection{Carbohydrates}

Total carbohydrates were determined by the direct method described by Safařík \& Šantrůčková (1992). About $0.25 \mathrm{~g}$ of soil sample was transferred to glass tubes and $1 \mathrm{~mL}$ of $72 \%$ sulfuric acid plus $20 \mathrm{~mL}$ of water were added. The glass tubes were placed in water bath at $104^{\circ} \mathrm{C}$ for $5 \mathrm{~h}$. Thereafter, once the tubes were cooled down, the suspension was filtered (Whatman No. 40) and the supernatant were as transferred to $50 \mathrm{~mL}$ ball flask. One milliliters of the extract was added to $4 \mathrm{~mL}$ of anthrone reagent
(4 $\mathrm{g}$ in $200 \mathrm{~mL}$ anthrone sulfuric acid), stirred and warmed in water bath at $80{ }^{\circ} \mathrm{C}$ for $10 \mathrm{~min}$. It was cooled on ice for 10 min and then the absorbance was measured at $660 \mathrm{~nm}$. The amount of reducing sugars released by microorganism was determined by the 3,5-dinitrosalicylic acid (DNS) method (Miller, 1959). DNS reagent was prepared by adding $1 \mathrm{~g}$ of DNS and $30 \mathrm{~g}$ of sodium potassium tartaric acid to $80 \mathrm{~mL}$ of $0.5 \mathrm{~N} \mathrm{NaOH}$. The solution was kept at 45 ${ }^{\circ} \mathrm{C}$ for the complete dissolution of the reagent and then cooled down at room temperature and diluted with distilled water to $100 \mathrm{~mL}$. The solution was stored for two weeks at $4{ }^{\circ} \mathrm{C}$. For the measurement, $0.4 \mathrm{~mL}$ of DNS reagent was added to $1 \mathrm{~g}$ of soil in tested tubes and they were kept at $95{ }^{\circ} \mathrm{C}$ for $5 \mathrm{~min}$. The absorbance was measured at $540 \mathrm{~nm}$.

\subsubsection{ATP}

ATP was extracted from soil using Webster et al. (1984) procedure and measured as recommended in Ciardi and Nannipieri (1990). Twenty milliliters of a phosphoric acid was added to $1 \mathrm{~g}$ of soil, the suspension was shaken in a cool bath, filtered through Whatman paper and an aliquot was used to measure the ATP by luciferin-luciferase assay in a luminometer (Optocomp 1, MGM Instruments, Inc.).

\subsection{Data analysis}

The ANOVA test and correlations amongst different soil properties were carried out by JPM software. All analyses were conducted with a significant $P$ value of 0.05 . Regression analysis to test the effect of soil properties on $\mathrm{C}$ mineralization were conducted following the approach used by Matus et al. (2006). The multiple regression analysis was carried out to test whether the combined effects significantly increased $\mathrm{R}^{2}$ values significantly compared with those of simple linear 
correlations. Multiple regression has been criticized because of the inclusion of a multiplicative term (or interaction), which is difficult to interpret (Garrido and Matus, 2012). In the present study, this disagreement was avoided using an additive model in which no multiplicative terms were included; we assumed that the effect of an independent variable strongly reflected the change of the dependent variable, regardless of the level of other effects (Garrido and Matus, 2012). The multiple regression analysis allowed us to perform a stepwise history and forward elimination. Mallow's criterion was used instead of the error mean square to select the best model. A model was selected when Mallow's criterion approached the probability value (0.05), and the number of parameters in the equation significantly increased the $\mathrm{R}^{2}$ values significantly. All data were tested for the normality of the distribution using a skewness test value of 0.5 (Webster and Oliver, 2001). If the skewness value was $>0.5$, we concluded that the distribution was not normal. All analyses were computed using JMP statistical software (SAS Institute, Cary, NC, and U.S.A).

\section{Results}

\subsection{Soil properties}

The total recovery from LF, IF and MF to total soil was close to $100 \%$. The proportion of MF in PAC soils was $55 \%$ compared with $34 \%$ of PNP soils (Table 2). The allophanic soils in PNP is silty loam (Neculman et al., 2012), whereas in kaolinitic metamorphic soil it is clay loam (Luzio et al., 2003). The SOC in both bulk soils was similar. However, the MF in PAC soil showed almost half the amount of SOC found in PNP and it was always lower in the other fractions too. The $\mathrm{Al}_{\mathrm{p}}$ (pyrophosphate) is an indicator of complexed $\mathrm{Al}$ with organic matter, particularly this indicator is important in volcanic soils. As expected, $\mathrm{Al}_{\mathrm{p}}$ in PNP doubled the amount found in PAC soil. The MB C obtained by fumigation and extraction varied between 0.9 and $3.8 \mathrm{~g}$ $\mathrm{C} \mathrm{kg}^{-1}$ soil and were similar in all fraction and bulk soil, except in LF of PAC soil. ATP followed the similar trends as for MB (Table 2).

\subsection{Incubation}

In all soils and fractions, the $\mathrm{C}$ mineralization was between 162 and $1000 \mathrm{mg} \mathrm{C}-\mathrm{CO}_{2} \mathrm{~kg}^{-1}$ soil after 30 days of incubation and it was always lower in PAC soil (Figure 1). Depending on the fraction, mineralization decreased as follow: $\mathrm{LF}>\mathrm{IF}>\mathrm{MF}$ in both soils (Figure $1 \mathrm{~A}$ and $1 \mathrm{~B})$. In general, the mineralized $\mathrm{C}$ tended to stabilize after 15 days of incubation (Figure 1C and 1D).

\subsection{Enzymes activity, carbohydrates and other soil parameters}

Enzymes secreted by soil microorganisms and various related soil properties at different fractions provided information about the potential activity of the soil microbial community. All soil enzymes, $\beta$-glucosidase $(\beta \mathrm{G})$, dehydrogenase $(\mathrm{DH})$, phosphatase $\left(\mathrm{P}_{\text {ase }}\right)$ and urease $(\mathrm{U})$ and carbohydrates (total, soluble and reducing sugars), inorganic $\mathrm{N}$ (ammonium and nitrate), inorganic $\mathrm{P}(\mathrm{Pi})$ and soil respiration were normally distributed [Shapiro-Wilk test $>0.05$ or skewness test value $<0.5$, Webster and Oliver (2001)]. The effect of Ah mineral horizons and physical fraction was analyzed by two way ANOVA. Significant effect was obtained for the interaction (soil $\mathrm{x}$ fraction) for $\beta \mathrm{G}$, $\mathrm{DH}, \mathrm{U}$ and reducing sugars (Table 3). However, soil respiration, the $\mathrm{C}-\mathrm{CO}_{2}$, phosphatase and Pi were only significant for soil and fraction. The enzyme activityafter 30 days of incubation is shown in Figure 2A and $2 \mathrm{~B}$. The $\beta \mathrm{G}$ and $\mathrm{DH}$ followed similar pattern in the bulk soil and fractions. Both enzymes were higher in PNP bulk soil in comparison with PAC soil (Table 2). 
Table 2. Soil and physical fractions characterization of studied temperate rain forest in Puyehue National Park (PNP) and Alerce Costero Nationl Park (PAC).

\begin{tabular}{lllllll}
\hline Forest & Fraction $^{1}$ & Proportion & SOC & $\mathrm{Al}_{\mathrm{P}}^{3}$ & $\mathrm{MB}-\mathrm{C}^{5}$ & $\mathrm{ATP}$ \\
& & $\%$ & $\mathrm{~g} \mathrm{~kg}^{-1}$ & $\mathrm{~g} \mathrm{~kg}^{-1}$ & $\mathrm{~g} \mathrm{~kg}^{-1}$ & $\mathrm{ng} \mathrm{g}^{-1}$ \\
\hline PNP & LF & $45.1 \pm 5$ & $271 \pm 4$ & $4.9 \pm 1.3$ & $3.8 \pm 0.8$ & $3.27 \pm 0.4$ \\
& IF & $20.6 \pm 3$ & $113 \pm 32$ & $7.2 \pm 0.2$ & $2.5 \pm 0.5$ & $0.92 \pm 0.0$ \\
& MF & $34.3 \pm 3$ & $205 \pm 6$ & $9.8 \pm 1.7$ & $3.8 \pm 1.2$ & $0.07 \pm 0.02$ \\
& Bulk & 100 & $99 \pm 15$ & $11.0 \pm 1.5$ & $3.8 \pm 0.5$ & $2.48 \pm 0.1$ \\
& PAC & $15.1 \pm 2$ & $95 \pm 12$ & $2.0 \pm 0.3$ & $0.9 \pm 0.6$ & $1.88 \pm 0.04$ \\
& IF & $30.4 \pm 1$ & $88 \pm 20$ & $1.2 \pm 0.0$ & $2.1 \pm 0.4$ & $0.99 \pm 0.1$ \\
& MF & $54.5 \pm 5$ & $119 \pm 6$ & $2.5 \pm 2.4$ & $2.5 \pm 0.4$ & $0.04 \pm 0.01$ \\
& Bulk & 100 & $110 \pm 7$ & $5.7 \pm 0.2$ & $3.4 \pm 0.8$ & $2.32 \pm 0.2$ \\
\hline
\end{tabular}

${ }^{1} \mathrm{LF}=$ light fraction, coarse sand 250-2000 $\mu \mathrm{m} ; \mathrm{IF}=$ intermediate fraction, fine sand 53-250 $\mu \mathrm{m}+$ particulate organic matter (POM) and $\mathrm{MF}=$ mineral fraction, silt and clay $<53 \mu \mathrm{m}$; ${ }^{2}$ Soil organic carbon by Wlkley and Black (1934);

${ }^{3}$ Aluminium extracted with Na-pyrophosphate; ${ }^{4} \mathrm{C}$ in the microbial biomass.

This situation was different in the fractions, where $\beta G$ and DH were significantly higher in MF of PAC soil. Urease did not follow consistent trends (Figure 2C). Phosphatase activity decreased as the fraction size diminished in both soils (Figure 2D).

Although the total and soluble carbohydrates were not significant, they showed consistent trend with $\beta G$ and DH (Figure 3A and 3B). This was particularly true for MF of reducing sugars.

\subsection{Simple and multiple regression analysis}

The coefficient of correlations amongst various soil properties were similar in both soils, therefore, only the results for PNP are shown (Table 4). The $\beta G$ and DH were highly correlated each other $(\mathrm{r}=0.53, P<$ 0.01 ) and both enzymes were correlated with soluble carbohydrates and reducing sugars. From Table 4 interesting results emerge. Soil respiration was positive and highly correlated with $\beta \mathrm{G}, \mathrm{DH}$, phosphatase, reducing sugars and inorganic $\mathrm{P}$. Therefore, reducing sugars were expected to be correlated with $\beta \mathrm{G}$, $\mathrm{DH}$ and phosphatase. Ammonium was inversely correlated with nitrate and highly correlated with soluble carbohydrates. In order to look at the response of $\mathrm{C}-\mathrm{CO}_{2}$ in the physical fraction isolated from PNP and PAC soils, a stepwise multiple regression (SMR) analysis was conducted. Table 5 shows the soil attributes for significant variables influencing $\mathrm{C}-\mathrm{CO}_{2}$ as calculated by increasing $\mathrm{R}^{2}$ in forward step. Similar result were obtained for bulk soils(not shown). The $\mathrm{C}-\mathrm{CO}_{2}$ variation due to several soil properties in Table 5 was similar to the relevant coefficient of correlation obtained in Table 4. Dehydrogenase, urease and phosphatase were common variables and they explained $>76 \%$ the $\mathrm{C}-\mathrm{CO}_{2}$ variation in PNP and PAC soils. Soluble and total carbohydrates were relevant variables in PAC soil, as well. 

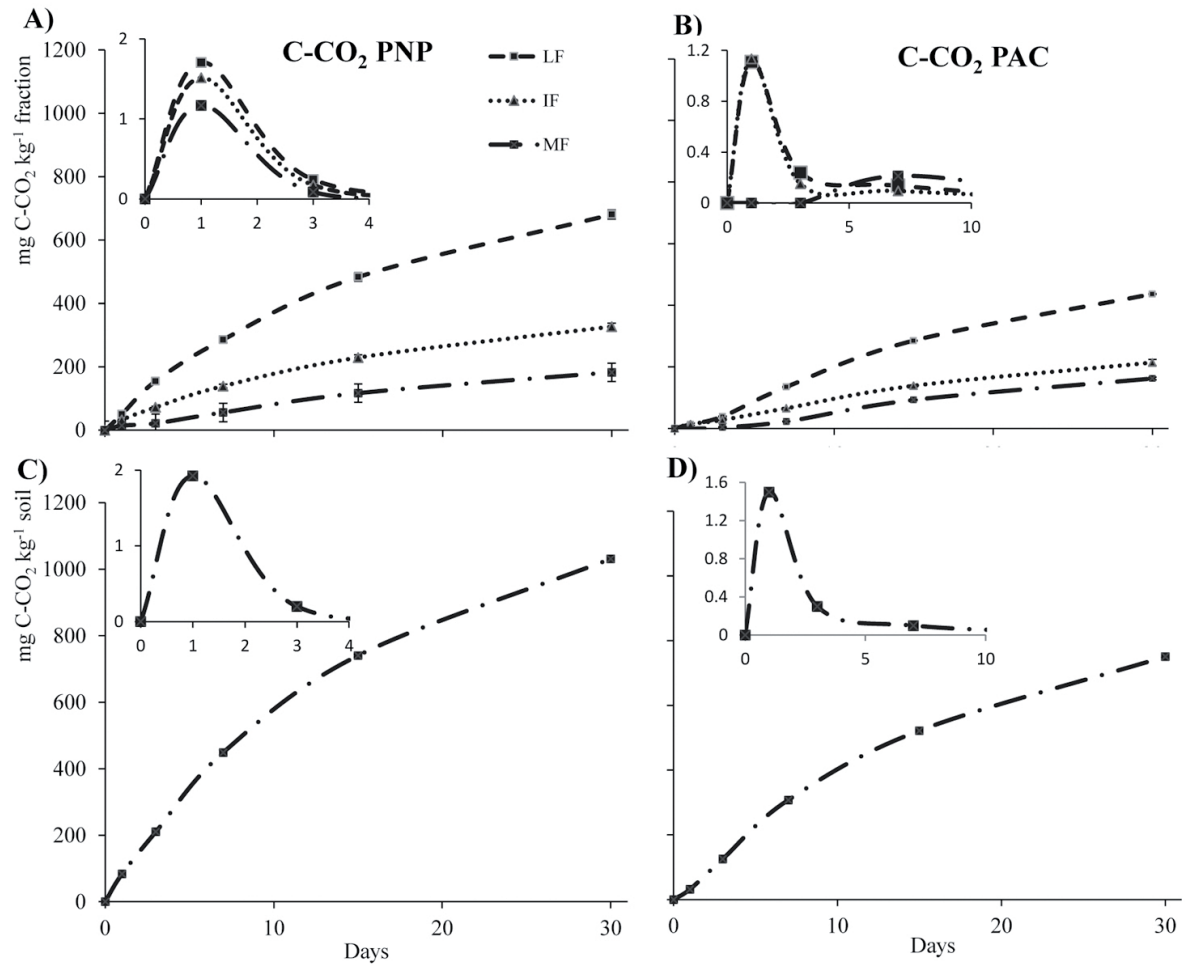

Figure 1. Carbon mineralization in the (A-B) soil fractions and (C-D) bulk soil from temperate rain forest in Puyehue National Park (PNP) and Alerce Costero Nationl Park (PAC).

Table 3. Significant effect of Ah mineral soil (allophanic and kaolinitic) and physical fraction (LF, IF and MF) on various biological and soil properties in temperate rain forest in Puyehue National Park (PNP) and Alerce

\begin{tabular}{|c|c|c|c|c|c|c|c|c|c|c|c|c|c|c|c|}
\hline & & & $\beta G$ & & $\mathrm{DH}$ & & $\mathrm{U}$ & & $\mathrm{P}_{a}$ & & RdSug & & Pi & & $\mathrm{C}-\mathrm{CO}_{2}$ \\
\hline Source of Variation & DF & F-ratio & Prob $>$ F & F-ratio & Prob $>F$ & F-ratio & Prob $>F$ & F-ratio & Prob $>F$ & F-ratio & Prob $>F$ & F-ratio & Prob $>F$ & F-ratio & Prob $>F$ \\
\hline Soil (A) & 1 & 0.02 & 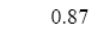 & 1.88 & 7 & 6 & 17 & 9.99 & 0.01 & 10 & 0.001 & 25 & 0.64 & 8.29 & 0.0 \\
\hline Fraction (B) & 2 & 3.63 & 0.03 & 3.54 & 0.03 & 0.834 & 0.43 & 11.55 & $<0.0001$ & 4.01 & 0.02 & 11.54 & $<0.001$ & 28.00 & $<0.0001$ \\
\hline $\mathrm{AxB}$ & 2 & 35.52 & $<0.0001$ & 33.20 & $<0.0001$ & 10.74 & $<0.001$ & 1.32 & 0.27 & 14.02 & $<0.0001$ & 0.23 & 0.80 & 2.20 & 0.12 \\
\hline
\end{tabular}

$\beta G=\beta$-Glucosidase, $\mathrm{DH}=$ Dehydrogenase, $\mathrm{U}=$ Urease, $\mathrm{Pase}=$ Acid phosphatase, $\mathrm{RdSug}=$ Reducing sugars, $\mathrm{Pi}=\mathrm{Olsen} \mathrm{P}$ 


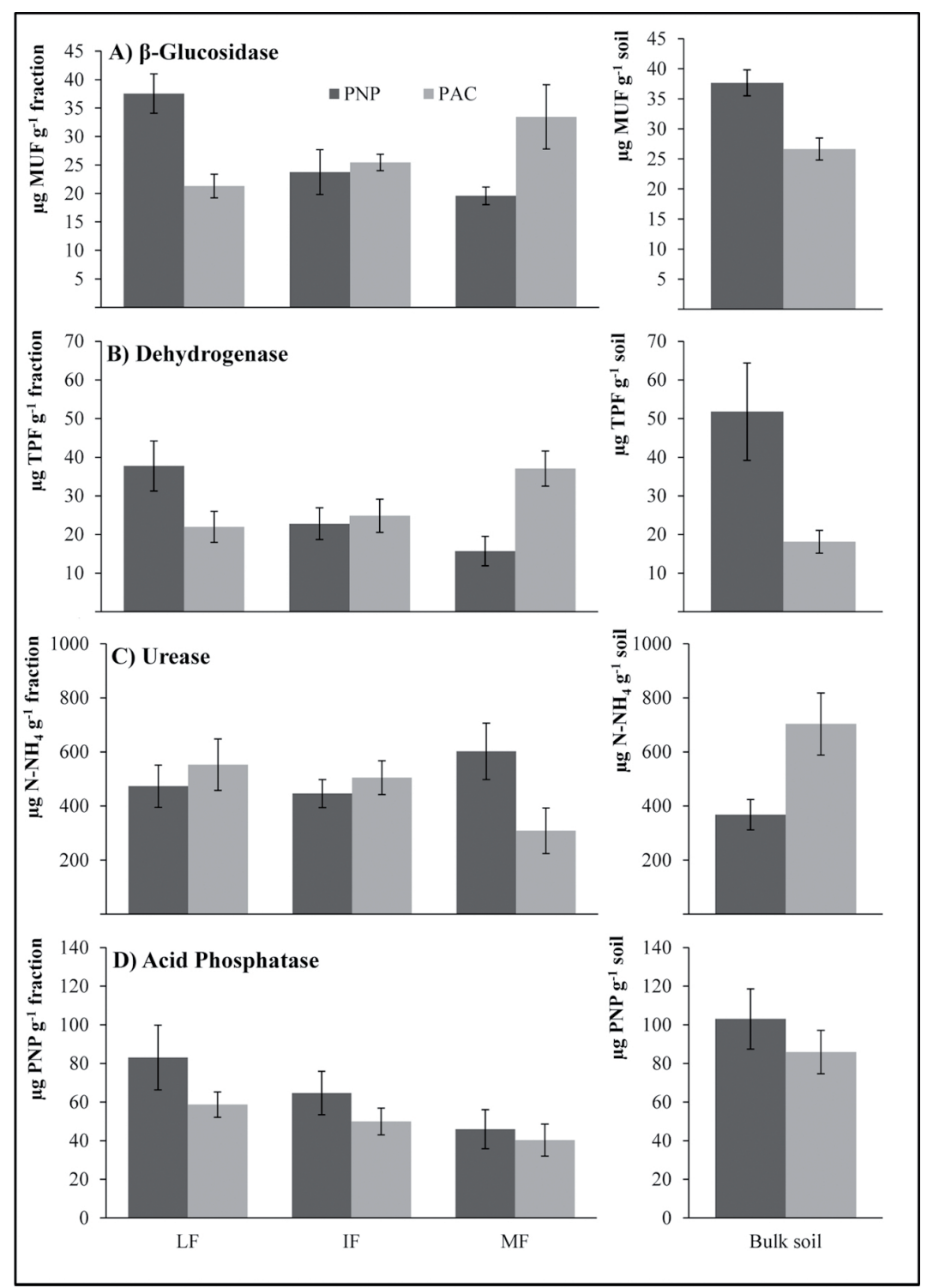

Figure 2. Average of enzymes activity after 30 days of incubation. (A) $\beta$-glucosidase ( $\beta G$ ), (B) dehydrogenase (DH), (C) urease and (D) phosphatase, in bulk soil from temperate rain forest in Puyehue National Park (PNP) and Alerce Costero Nationl Park (PAC). 


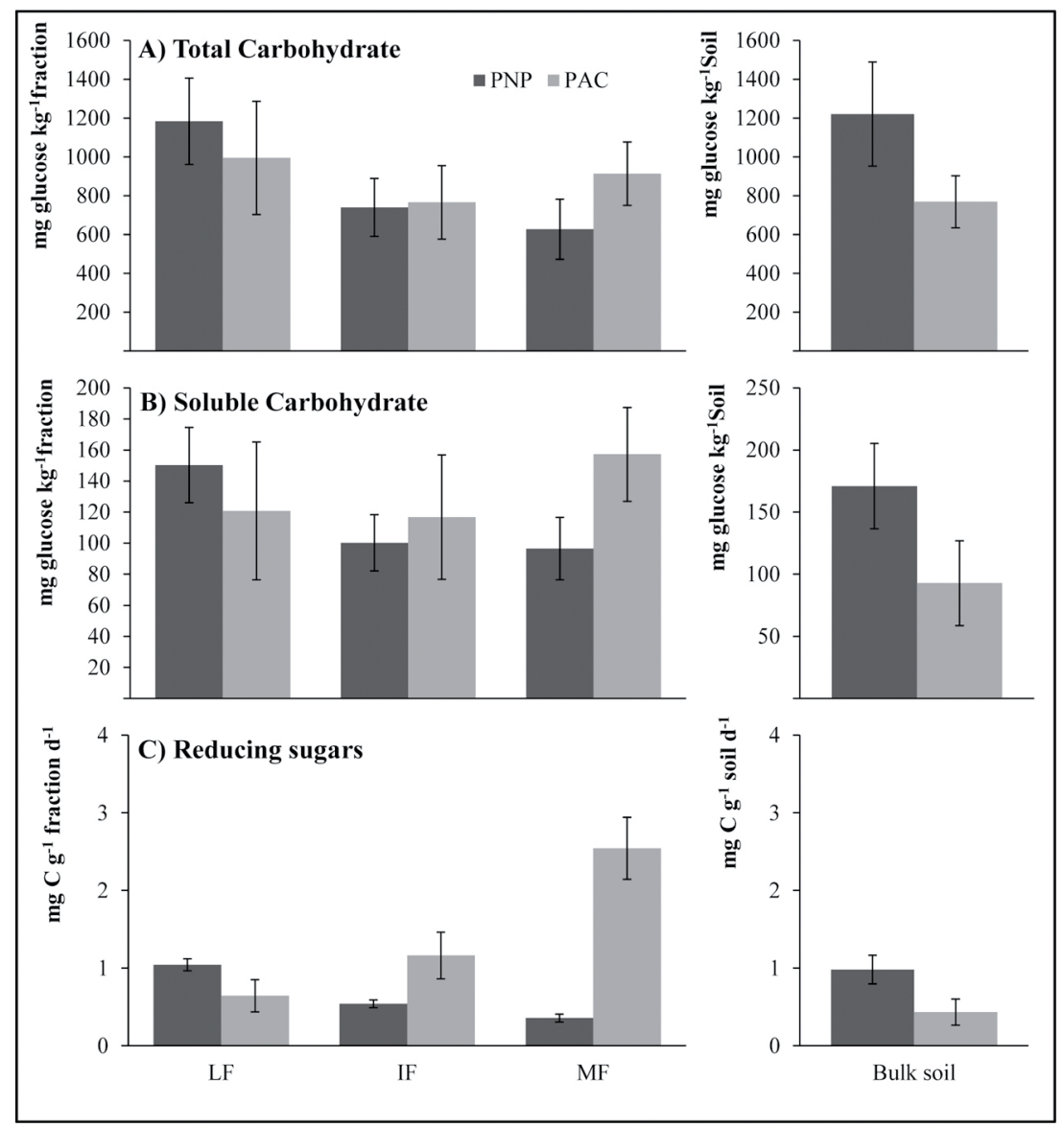

Figure 3. Average of enzymes activity after 30 days of incubation. (A) Total carbohydrate (CHOt), (B) soluble carbohydrate (CHOs) and (C) Reducing sugar, in bulk soil and fractions from temperate rain forest in Puyehue National Park (PNP) and Alerce Costero Nationl Park (PAC).

\subsection{Carbon stabilization}

The soil metabolic quotient $\left(q \mathrm{CO}_{2}\right)$, the respiration rate $\mathrm{C}-\mathrm{CO}_{2}$ mineralized between 15 and 30 days divided by microbial biomass $\mathrm{C}$ was used as indicator of $\mathrm{C}$ metabolic efficiency for microorganisms (Anderson and Domsch, 1990) There was a highly significant correlation with $q \mathrm{CO}_{2}$ and ATP and ATP, in turn,was highly correlated with the cumulative $\mathrm{C}-\mathrm{CO}_{2}$ at $15-30$ days of incubation too (Figure 4).

The $\mathrm{C}$ stabilization is evaluated by the relationship between $\mathrm{Al}_{\mathrm{p}}$, (Al bound to SOM) and the $\mathrm{C}-\mathrm{CO}_{2}$ mineralized between 15-30 days of incubation. For PNP soil, there was an inverse and significant relationship, which was not the case for PAC soil (Figure 5). 
Table 4. Coefficient of correlation (R) amongst various soil properties in different physical fractions (LF, IF and MF) of allophanic soil in temperate rain forest in Puyehue National Park (PNP).

\begin{tabular}{|c|c|c|c|c|c|c|c|c|c|c|}
\hline Variable & $\beta \mathrm{G}$ & $\mathrm{DH}$ & $\mathrm{U}$ & $P_{\text {ase }}$ & TotCH S & SolCH RdSu & ig N-NC & $\mathrm{O}_{3} \quad \mathrm{~N}-\mathrm{NH}_{4}$ & $4 \quad \mathrm{Pi}$ & $\mathrm{C}-\mathrm{CO}_{2}$ \\
\hline$\beta G$ & 1.0 & & & & & & & & & \\
\hline DH & $0.53 * *$ & 1.0 & & & & & & & & \\
\hline U & -0.11 & -0.16 & 1.0 & & & & & & & \\
\hline $\mathrm{AP}_{\text {ase }}$ & 0.16 & $0.63 * *$ & -0.04 & 1.0 & & & & & & \\
\hline TotCH & $0.35^{* *}$ & $0.24^{*}$ & 0.18 & $0.24 *$ & 1.0 & & & & & \\
\hline SolCH & $0.21 *$ & $0.26^{*}$ & 0.00 & 0.16 & $0.32 *$ & 1.0 & & & & \\
\hline RdSug & $0.75 * *$ & $0.62^{*}$ & 0.01 & $0.47 * *$ & $* 0.66^{* * *}$ & * $0.49 * *$ & 1.0 & & & \\
\hline $\mathrm{N}-\mathrm{NO}_{3}$ & 0.01 & 0.12 & -0.06 & 0.20 & $-0.24^{*}$ & $-0.69^{* *}$ & -0.19 & 1.0 & & \\
\hline $\mathrm{N}-\mathrm{NH}_{4}$ & 0.04 & 0.06 & 0.16 & -0.03 & $0.22 *$ & $0.52 * *$ & $0.23^{*}$ & $-0.52 * *$ & 1.0 & \\
\hline Pi & 0.14 & $0.74 * *$ & -0.19 & $0.80 * *$ & * 0.04 & $0.26^{*}$ & $0.35 * *$ & 0.11 & 0.03 & 1.0 \\
\hline $\mathrm{C}-\mathrm{CO}_{2}$ & $0.63 * *$ & $0.66^{* *}$ & $-0.38^{*}$ & $0.48^{* * *}$ & * $0.21 *$ & 0.09 & $0.54 * *$ & $0.21^{*}$ & $-0.33 * *$ & $0.50^{* *}$ \\
\hline
\end{tabular}

$\mathrm{LF}=$ light fraction; $\mathrm{IF}=$ intermediate fraction; $\mathrm{MF}$ mineral fraction; $\beta \mathrm{G}=\beta$-Glucosidase, $\mathrm{DH}=$ Dehydrogenase; $\mathrm{U}=$ Urease; $\mathrm{P}_{\text {ase }}=$ Acid phosphatase; $\mathrm{Tot} \mathrm{CH}=$ Total carbohydrates; $\mathrm{SolCH}=$ Soluble carbohydrates; RdSug= Reducing sugars; Nitrate $=$ $\mathrm{N}-\mathrm{NO}_{3} ;$ Ammonium $=\mathrm{N}-\mathrm{NH}_{4} ; \mathrm{Pi}=$ Olsen $\mathrm{P} ; * * P<0.001 ; * P<0.05$.

Table 5. Contribution of various soil parameter on soil $\mathrm{C}$ respiration of physical fractions using step wise multiple regression analysis from temperate rain forest in Puyehue National Park (PNP) and Alerce Costero Nationl Park (PAC).

\begin{tabular}{|c|c|c|c|c|c|}
\hline Forest & Parameter & $\mathrm{R}^{2}$ & Estimate & F-ratio & Prob> F \\
\hline \multicolumn{6}{|l|}{ PNP } \\
\hline & Intercept & & 7.32 & 0.00 & 1.00 \\
\hline & DH & 0.44 & 1.28 & 5.46 & 0.02 \\
\hline & $\mathrm{N}-\mathrm{NH}_{4}$ & 0.58 & -0.26 & 15.75 & 0.00 \\
\hline & $\beta G$ & 0.69 & 2.52 & 20.11 & 0.00 \\
\hline & U & 0.73 & -0.07 & 7.67 & 0.01 \\
\hline & $\mathrm{P}_{\text {ase }}$ & 0.76 & 0.39 & 3.98 & 0.05 \\
\hline \multicolumn{6}{|l|}{ PAC } \\
\hline & Interce & & -26.065 & 0.00 & 1.00 \\
\hline & SolCH & 0.58 & -0.368 & 60.46 & 0.00 \\
\hline & $P_{\text {ase }}$ & 0.67 & 0.52 & 4.12 & 0.05 \\
\hline & $\mathrm{Pi}$ & 0.74 & 0.34 & 10.32 & 0.00 \\
\hline & Tot & 7 & 0.033 & 10.00 & 0.00 \\
\hline & U & 0.78 & 0.06 & 6.47 & 0.02 \\
\hline & DH & 0.80 & 0.97 & 3.39 & 0.05 \\
\hline
\end{tabular}



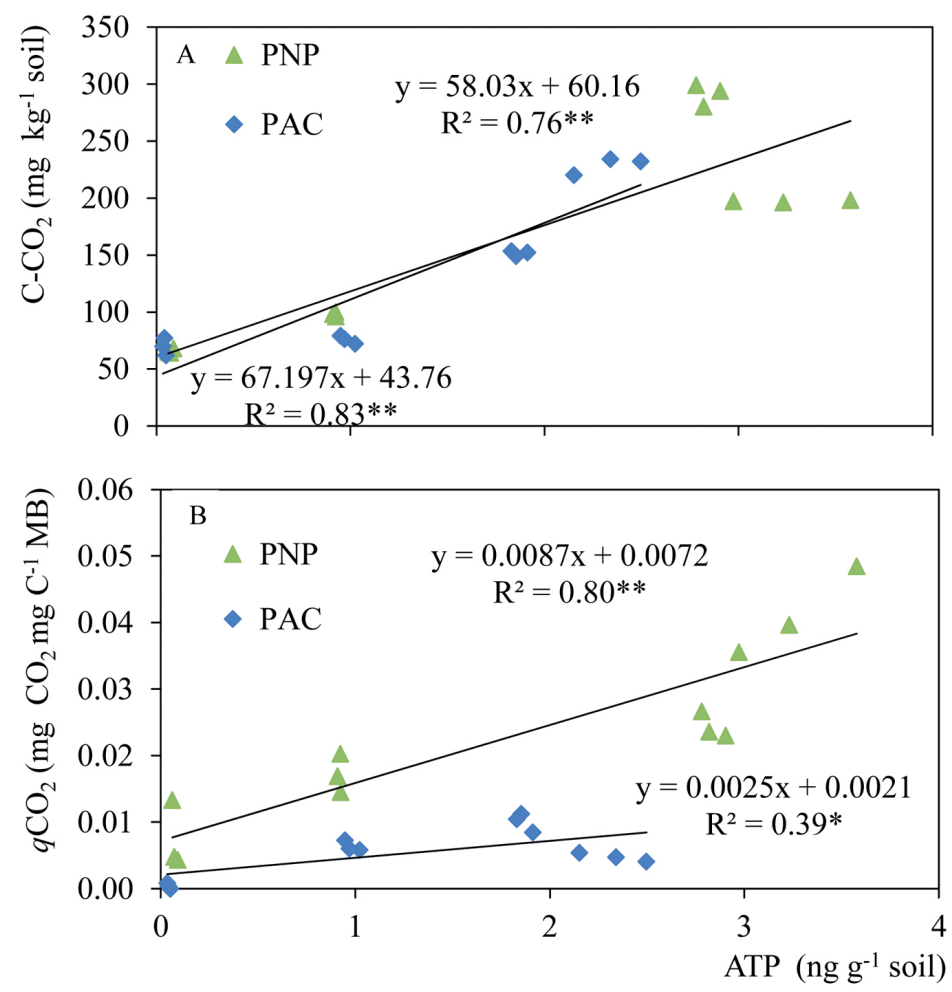

Figure 4. Relationship between ATP and (A) $\mathrm{C}-\mathrm{CO}_{2}$, (B) $q \mathrm{CO}_{2}$ at 15-30 days of days of incubation from the bulk soil and the physical fractions isolated from Puyehue National Park (PNP) and Alerce Costero Nationl Park (PAC). ${ }^{*} p<0.05$ and $* * P<0.01$

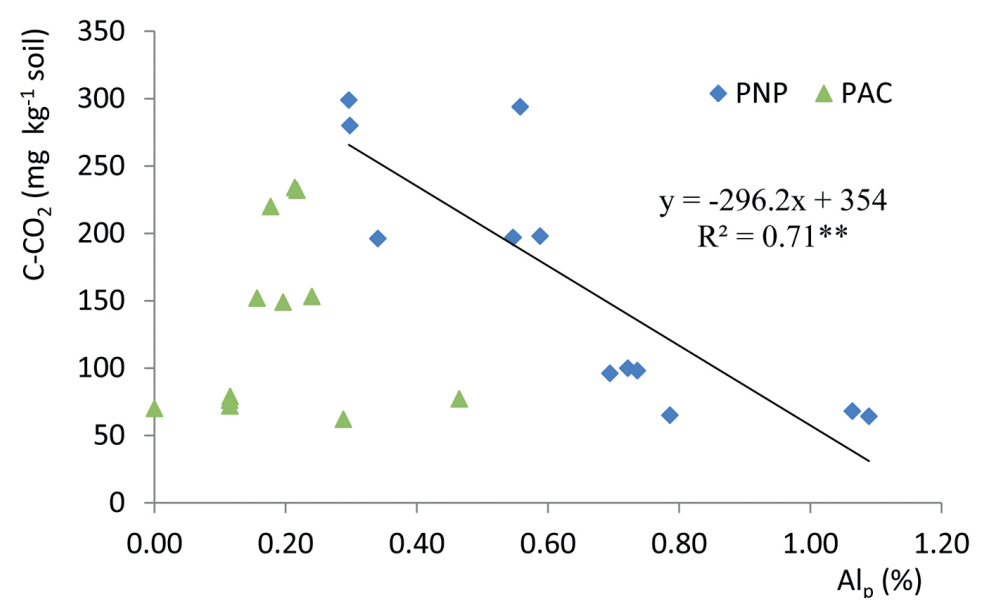

Figure 5. Relationship between $\mathrm{Al}$ pyrophosphate and $\mathrm{C}-\mathrm{CO}_{2}$ at $15-30$ days of incubation in the bulk soil and in the physical fraction isolated from Puyehue National Park (PNP) and Alerce Costero Nationl Park (PAC). * $p<$ 0.05 and $* * P<0.0$ 


\section{Discussion}

\subsection{Mineral control on biological activity and C sta- bilization}

The present research was carried out in two soils from forest ecosystems developed from volcanic ash (allophanic) and metamorphic schist (kaolinitic). The influence of soil mineralogy on $\mathrm{C}$ stabilization in the bulk soil and different physical fractions was evaluated. The biological activity in response to the soil mineral composition and physical fractions were assumed to represent the level of SOM stability that provided valuable information on $\mathrm{C}$ mineralization stabilization mechanism.

The enzyme activity in the soil amended with cellulose were significant different by the effect of soil type and the fractions and these result were consistent with those obtained with multiple regression analysis. Both, $\beta \mathrm{G}$ and $\mathrm{DH}$ activity were highly correlated with the release of $\mathrm{C}-\mathrm{CO}_{2}, \mathrm{r}=0.63$ and $\mathrm{r}=0.66$, respectively. In general, the respiration was correlated with phosphatase, reducing sugar and inorganic $\mathrm{P}$, indicating the importance of $\beta \mathrm{G}$ and $\mathrm{DH}$ activity for degrading labile organic compounds at expenses of inorganic $\mathrm{P}$ in both soils. The amount of $\beta$-glucosidase and dehydrogenase decreased in MF of PNP, while the opposite pattern was found in the same fractions in PAC soil. Soil organic matter in the MF of PNP is complexed with $\mathrm{Al}$ oxides and short-range ordered (SRO) minerals, (allophane like-materials, Garrido and Matus, 2012; Neculman et al., 2012), Recently, it has been recognized that SOM can be micro-encapsulated inside of highly and this is an important mechanism of C stabilization (Asano and Wagai, 2014; Chevallier et al., 2010). This contrasts with the lower stabilization capacity in kaolinitic, 1:1 clay mineral soil.

Multiple regression analysis indicated that $\beta$-glucosidese and dhydrogenase, together with urease, phosphatase and Pi explained $>76 \%$ the variation of soil $\mathrm{C}$ respiration in both amended soils. Spite of the reduced $\mathrm{C}$ mineralizationin $\mathrm{PAC}$, the greatest activity of $\beta$-glucosidase, and dehydrogenase was registered in the MFdue to a reduced stabilization capacity (Luzio et al., 2003) (see below). The latter was attributed to the inhibitory effect of free $\mathrm{Al}$ reflected in a lower $\mathrm{pH}$ of PAC (4.6) compared with PNP (6.2) soil. The percentage of Al saturation in PAC soil was extremely high (Table 1).

Our findings appear to be consistent with the model of cellular metabolism, where $\mathrm{N}$ limits microbial biomassto build proteins, but the rates of protein synthesis are limited by the high $\mathrm{P}$ demands as supported by the high correlation of $\mathrm{C}-\mathrm{CO}_{2}$ and phosphatase activity. Incorporation of these physiological processes may improve models of carbon cycling and understanding of the effects of nutrient availability on soil C turnover across terrestrial ecosystems.

\subsection{Relationship between metabolic quotient $\left(\mathrm{qCO}_{2}\right)$ and $C$ stabilization}

The metabolic quotient $\left(q \mathrm{CO}_{2}\right)$ or the specific respiration rate, the total amount of $\mathrm{C}-\mathrm{CO}_{2}$ mineralized between 15 and 30 days divided by microbial biomass $\mathrm{C}$ was positive and highly correlated with ATP in the bulk and physical fractions. The ATP was also correlated with the $\mathrm{C}-\mathrm{CO}_{2}$ on 15-30 days of incubation. It is possible that the differences in the $q \mathrm{CO}_{2}$ along the ATP variation can be due to the microbial composition in different fractions. Microbial community structure is affected by particle size significantly, yielding higher diversity of microbes in small size fractions than in coarse size fractions (Sessitsch et al., 2001). The mineralogical composition of soil showed an important role in the $\mathrm{C}$ mineralization, since there was an inverse and significant relationship between $\mathrm{Al}_{\mathrm{p}}$ (Al bound to SOM) and the $\mathrm{C}-\mathrm{CO}_{2}$ for PNP 
but no for PAC soil (Figure 5). This relationship was expected to occur only in volcanic soils, because of the potential of $\mathrm{Al}_{\mathrm{p}}$ to complexes SOM (Matus et al., 2014). However, in kaolinitic soils, more crystallinity clay exerted a small stabilizing effect. In previous studies, Al-SOM complexes was the primary factor explaining soil $\mathrm{C}$ variation in similar soils rather than climatic variables and clay content (Percival et al., 2000; Matus et al., 2006). Neculman et al. (2012) found an inverse relationship between soil $\mathrm{pH}$ and $\mathrm{C}$ pyrophosphate, supporting the hypothesis that the AlSOM complexes and allophane formation are inverse, although complementary processes are mainly regulated by soil pH (Garrido and Matus, 2012; Panichini et al., 2012). In the present study, the PNP in volcanic soil with pH 6.2 could promote the allophane polymerization and thereafter SOM sorption. It is also well known that others factors, than $\mathrm{pH}$ such as the stability constants of metals and/or the concentration of competing $\mathrm{Fe}$ and $\mathrm{Al}$ aqueous species also influence the degree of complexation (Dahlgren et al., 2004). Marino et al. (personal communication) established that MF of PNP soil had the lowest $\mathrm{C}$ priming in comparison with the same fraction in PAC soil. This indicated the reduced availability of organic $\mathrm{C}$ for soil microbes due to clay mineralogy (allophane and imogolite, with high potential for Al-SOM complexes formation). Jones and Edwards (1998) reported that simple C substrates (glucose and citrate) added to kaolinite and illite-mica were more decomposable than those added to ferric hydroxide. Zunino et al. (1982) noted a decreased in C mineralization when allophonic materials were added to non-volcanic soil. The chemical bonding between SOM and mineral surfaces decreased the availability of $\mathrm{C}$ to microorganisms (Guggenberger and Kaiser, 2003). Clay minerals have specific surface areas; therefore, it may be expected that clay type influences the capacity of soils to hold organic $\mathrm{C}$.

\section{Conclusions}

We examined C stabilization capacity of two pristine temperate rain forest soils; allophanic and kaolinitic soils. The soils were physically fractionated in light (LF, coarse sand $>250 \mu \mathrm{m}$ ), intermediate (IF, fine sand 50-250 $\mu \mathrm{m}$ ) and mineral (MF, silt and clay < $53 \mu \mathrm{m})$. Biological activity was evaluated. Soil type and the physical fractions had a significant impact on all enzyme activities. More than $76 \%$ of total $\mathrm{C}-\mathrm{CO}_{2}$ in PNP and $80 \%$ in PAC soil were explained by the combination of $\beta$-glucosidase, dehydrogenase, urease and phosphatase using stepwise multiple regression analysis. Mineral fraction of PNP containing allophanic-like materials, unlike PAC with dominant kaolinitic clay, showed the lowest enzymatic activity, except for urease and phosphatase. The ATP was highly correlated with i) $\mathrm{C}-\mathrm{CO}_{2}$ at $15-30 \mathrm{~d}$ of incubation and ii) $\mathrm{qC}-\mathrm{CO}_{2}$ (respiration rate divided by microbial biomass). These results were in line with an inverse relationship found between Alp ( $\mathrm{Al}$ bound to SOM) and $\mathrm{C}-\mathrm{CO}_{2}$, indicating the large stabilization capacity of allophanic compared with kaolinitic soils.

\section{Acknowledgements}

The authors thank to CONICYT-Chile for their financial contributions through FONDECYT Projects 1130193 and Insertion Project of Advanced Human Capital in the Chilean Privet Sector, 781301003.

\section{References}

Anderson, T-H., Domsch, K.H. 1990. Application of eco-physiological quotients $\left(q \mathrm{CO}_{2}\right.$ and $\left.q \mathrm{D}\right)$ on microbial biomasses from soils of different cropping histories. Soil Biology and Biochemistry. 22, 251-255. 
Asano, M., Wagai, R. 2014. Evidence of aggregate hierarchy at micro- to submicron scales in an allophanic Andisol. Geoderma. 216, 62-74.

Balesdent, J., Pétraud, J., Feller, C. 1991. Effets des ultrasons sur la distribution granulométrique des matières organiques des sols. Science du sol. 29, 95-106.

Barberán, A., Ramirez, K.S., Leff, J.W., Bradford, M.A., Wall, D.H., Fierer, N. 2014. Why are some microbes more ubiquitous than others? Predicting the habitat breadth of soil bacteria. Ecology Letters. 17, 794-802.

Carreiro, M.M., Insabaugh, R.L.S., Epert, D.A.R., Arkhurs, D. F. P. 2000. Microbial enzyme shifts explain litter dacay response to simulated nutrogen deposition, Ecology. 81, 2359-2365.

Chevallier, T., Woignier, T., Touceta, J., Blancharta, E. 2010. Organic carbon stabilization in the fractal pore structure of Andosols. Geoderma. 159, 182-188.

Christensen, B., 1992. Physical Fractionation of soil and organic matter in primary particle size and density separates. In B.A. Stewart, ed. Advances in Soil Science SE - 1. Advances in Soil Science. Springer New York, pp. 1-90.

Dahlgreen, R.A., Saigusa, M., Ugolini, F.C. 2004. The Nature, properties and management of volcanic soils. Advances in Agronomy. Academic Press.

Dornbush, M.E. 2007. Grasses, litter, and their interaction affect microbial biomass and soil enzyme activity. Soil Biology and Biochemistry. 39, 22412249.

Eivazi, F., Tabatabai, M.A. 1988. Glucosidases and galactosidases in soils. oil Biology and Biochemistry. 20, 601-606.

Garrido, E., Matus, F. 2012. Are organo-mineral complexes and allophane content determinant factors for the carbon level in Chilean volcanic soils?. Catena. 92, 106-112.
Godoy, R., Oyarzún, C., Gerding, V. 2001. Precipitation chemistry in deciduous and evergreen Nothofagus forests of southern Chile under a low-deposition climate. Basic and Applied Ecology. 2, 65-72.

Guggenberger, G., Kaiser, K. Dissolved organic matter in soil: challenging the paradigm of sorptive preservation. Geoderma. 113, 293-310.

Hammel., K.E. 1997. Fungal degradation of lignin. In Plant Litter Quality and Decomposition (eds G. Cadisch and K.E. Giller). Cab International Driven by Nature, pp 33-45.

Jastrow, J.D. 1996. Soil aggregate formation and the accrual of particulate and mineral-associated organic matter. Soil Biology and Biochemistry. 28, 665-676.

Jolivet, C., Arrouays, D., Lévèque, J., Andreux, F., Chenu, C. 2003. Organic carbon dynamics in soil particle-size separates of sandy Spodosols when forest is cleared for maize cropping. European Journal of Soil Science. 54, 257-268.

Jones, D.L., Edwards, A.C. 1998. Influence of sorption on the biological utilization of two simple carbon substrates. Soil Biology and Biochemistry. 30, 1895-1902.

Kemper, W.D., Koch, E.J. 1966. Aggregate stability of soils from western United States and Canada; measurement procedure, correlations with soil constituents. Technical Bulletin. United States Department of Agriculture, Agricultural Research Service, $52 \mathrm{pp}$.

Kuzyakov, Y. 2010. Priming effects: Interactions between living and dead organic matter. Soil Biology and Biochemistry. 42, 1363-1371.

Levin, S.A. 1992. The Problem of Pattern and Scale in Ecology: The Robert H. MacArthur Award Lecture. Ecology. 73(6), pp.1943-1967.

Luzio, W., Sadzawka, A., Besoain, E., Lara, P. 2003. Influence of volcanic materials on red clay soilgenesis. Revista Chilena de Ciencia del suelo y Nutrición Vegetal. 3, 37-52. 
Masciandaro, G., Fornasier, F., Moscatelli, M. C., Marinari, S. 2012. Soil enzymology: classical and molecular approaches. Biology and Fertility of Soils. 48, 743-762.

Matus, F., Amigo, X., Kristiansen, S.M. 2006. Aluminium stabilization controls organic carbon levels in Chilean volcanic soils. Geoderma. 132, 158-168.

Matus, F., Garrido, E., Seúlveda, N., Cárcamo, I., Panichini, M., Zagal, E. 2008. Relationship between extractable $\mathrm{Al}$ and organic $\mathrm{C}$ in volcanic soils of Chile. Geoderma. 148, 180-188.

Matus, F. Rumpel, C., Neculman, R., Panichini, M., Mora, M.L. 2014. Soil carbon storage and stabilisation in andic soils: A review. Catena. 120, 102-110.

Neculman, R., Rumpel,C., Matus, F., Godoy, R., Steffens, M., Mora, M.L. 2012. Organic matter stabilization in two Andisols of contrasting age under temperate rain forest. Biology and Fertility of Soils. 49, 681-689.

Nie, M., Pendall, E., Bell, C., Gasch, C.K., Raut, S., Tamang, S., Wllestein, M.D. 2013. Positive climate feedbacks of soil microbial communities in a semi-arid grassland. Ecology letters. 16, 234-41.

Nannipieri, P., Ceccanti, B., Cervbelli, S., Matarese, E. 1980. Extraction of phosphatase, urease, proteases, organic carbon, and nitrogen from soil. Soil Science Society of America Journal. 44, 1011-1016.

Oyarzún, C.E., Godoy, R., De Schrijver, A., Staelens, J., Lust, N. 2004. Water chemistry and nutrient budgets in an undisturbed evergreen rainforest of Southern Chile. Biogeochemistry. 71, $107-123$.

Olsen, S.R., Cole, C.V., Watanabe, F.S., Dean, L.A. 1954. Estimation of available phosphorus in soils by extraction with sodium bicarbonate. USDA Circular 939. US Government Printing Office, Washington, DC.
Panichini, M., Matus, F., Mora, M.L., Godoy, R., Bolan, N.S., Rumpel, C., Borie, F. 2012. Carbon distribution in top- and subsoil horizons of two contrasting Andisols under pasture or forest. European Journal of Soil Science, 63. 616-624.

Percival, H.J., Parfitt, R.L., Scott, N.A. 2000. Factors controlling soil carbon levels in New Zealand grasslands. Is clay content important? Soil Science Society of America Journal. 64, 1623-1630.

Post, E. Brodie, J., Hebblewhite, M., Anders, A.D., Maier, J.A.K., Wilmers, C.C. 2009. Global Population dynamics and hot spots of response to Climate Change. BioScience. 59, 489-497.

Rasmussen, C., Southard, R.J., Horwath, W.R. 2006. Mineral control of organic carbon mineralization in a range of temperate conifer forest soils. Global Change Biology. 12, 834-847.

Safař́k, I.V.O., Šantrůčková, H. 1992. Direct determination of total soil carbohydrate content. Plant and Soil. 143, 109-114.

Sessitsch, A., Weilharter, A., Gerzabek, M.H., Kirchmann, H. Kandeler, E. 2001. Microbial population structures in soil particle size fractions of a long-term fertilizer field experiment. Applide and Environemntal Microbiology. 67, 4215-4224.

Sinsabaugh R.L., Antibus R.K, Linkins, A.E. 1991. An enzymic approach to the analysis of microbial activity during plant litter decomposition. AgricEcosyst Environ. 34, 43-54.

Six, J., Conant, Paul, E.A., Pautian, K. 2002. Stabilization mechanisms of soil organic matter: implications for C-saturation of soils. Plant and soil. 241, 155-176.

Tabatabai, M.A., Bremner., J.M. 1969. Use of pnitrophenyl phosphate for assay of soil phosphatase activity. Soil Biology and Biochemistry. 1, 301-307. 
Tabatabai, M., 1982. Soil enzymes. In: Page, A., E. Millar and D. Kenney (eds.). Part 1.Methods of soil analysis. Part 2. Chemical and microbiological properties.American Society of Agronomy, Madison. 1159 p.

Van Gestel, M., Merckx, R., Vlassak, K. 1996. Spatial distribution of microbial biomass in microaggregates of a silty-loam soil and the relation with the resistance of microorganisms to soil drying. Soil Biology and Biochemistry. 28, 503-510.

Vance, E.D., Brookes, P.C., Jenkinson, D.S. 1987. An extraction method for measuring soil microbial biomass C. Soil Biology and Biochemistry. 19, 703-707.

Waldrop, M.P., Zak, D.R., Sinsabaugh, R.L., Gallo, M., Lauber, C. 2004. Nitrogen deposition modifies soil carbon storage through changes in microbial enzymatic activity.Ecological Applications. $14,1172-1177$.
Webster, J.J., Hampton, G.J., Franklin R.L. 1984. ATP in soil: A new extractant and extraction procedure. Soil Biology and Biochemistry. 16, 355-342.

Webster, R., Oliver, M.A., 2001. Geostatistics for Environmental Scientists (Statistics in Practice). JohnWiley \&Sons, Ltd. The Atrium, Southern gate, Chichester, West Sussex, P.O 19 8SQ, UK.

Zhao, M., Xue, K., Wang, F., Liu, S., Bai, S., Sun, B., Zhou, J., Yang, Y. 2014. Microbial meWebster, J.J., Hampton, G.J., Franklin R.L. 1984. ATP in soil: A new extractant and extraction procedure. Soil Biology and Biochemistry. 16, 355-342.

Zunino, H., Borie, F., Aguilera, S., Martin, J.P., Haider, K. 1982. Decomposition of ${ }^{14} \mathrm{C}$-labeled glucose, plant and microbial products and phenols in volcanic ash-derived soils of Chile, 14, $37-43$ 